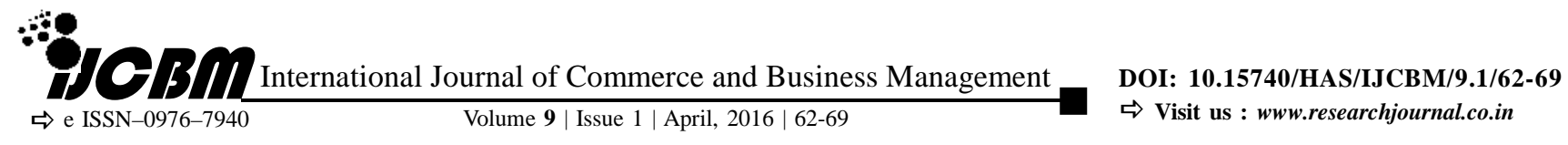

RESEARCH PAPER

\title{
Human skill development: A road ahead
}

A. M. GURAV

\begin{abstract}
Human skills are most demanded in all sectors for mobilizing other resources. There is a shortage of skills in comparison with demand of skills. NSDC has stared PPP in India for upgrading skill of Indian workforce, with the target of skilling 500 million people by 2022 and signed agreement with Australian Government on 23-10-2012. The researcher has interviewed 2405 sample respondents from 16 areas from Kolhapur district for study. Researcher has forced on skill gap percentage and skill building expenses for a year and 10 year. He suggested Cara-Van, Employee Bank, Finishing School concept and developed Employability Index to face competitive environment.
\end{abstract}

KEY WORDS : Skill gap, PPP, Cara-van, Employee bank, Finishing school, Employability index

How to cite this paper : Gurav, A.M. (2016). Human skill development: A road ahead. Internat. J. Com. \& Bus. Manage, 9(1) : 62-69.

Email: annsahebg@yahoo.co.in 